\title{
Effect of different levels of water on qualitative characteristics of Lassi prepared from reconstituted milk
}

\author{
Zohra FT, MN Islam*, MSR Siddiki, MR Habib and S Afrin
}

Department of Dairy Science, Bangladesh Agricultural University, Mymensingh-2202, Bangladesh

\begin{abstract}
Present research work was designed to develop lassi from reconstituted milk using different levels of water. For this purpose, dahi was prepared from reconstituted milk using traditional starter culture. Four different types of lassi were prepared by mixing dahi with 15, 20, 25 and 30\% water and sugar level in all samples were $20 \%$. The quality of lassi from reconstituted milk was evaluated by a panel of expert judges by different physical tests using a score card. There was non-significant difference $(p>0.05)$ among the overall physical score of lassi samples. Result revealed that the highest overall score was recorded in $20 \%$ added water lassi sample whereas the lowest score was found in $30 \%$ added water lassi sample. In chemical analysis, significant differences $(p<0.01)$ existed among the total solids, carbohydrate, fat, protein, moisture content and $\mathrm{pH}$ value but non-significant differences $(p>0.05)$ were seen for ash content and acidity percentage. The total bacteria, coliform, yeast and mold in all samples did not exceed the legal standard. From the findings of this study, it might be concluded that lassi could be prepared successfully from reconstituted and mixing reconstituted milk dahi with $20 \%$ water along with $20 \%$ sugar will produce better quality lassi.
\end{abstract}

Key words: dahi, physical, chemical, micobiological qualities, lassi

Bangladesh Animal Husbandry Association. All rights reserved. $\quad$ Bang. J. Anim. Sci. 2016. 45 (3): $46-51$

\section{Introduction}

Milk is highly nutritious food containing all nutrients required for normal functioning of the body system. It can be converted into various milk products that are classified into fermented and non-fermented one. The fermented milk products are dahi, yoghurt, lassi, (Ripned) butter milk and cheese etc. Lassi is a refreshing fermented summer drink originated from the subcontinent of India which gained its popularity worldwide. It is made of sour curd which made by lactic culture and a mixture of different ingredients like desiccated coconut, fruits, spices and sugar etc. It is popular for its health benefits such as ward off the heat in summer, prevents dehydration and also helps indigestion. In a laboratory, lassi drink made using one bowl of yogurt, 1 cup of water, few mints leaves, half tsp of black salt and 1 tsp grinded cumin seeds. Lassi can be made either sweet or savory and sweet lassi is thicker and creamy. Now a day's people prefer fermented milk beverage because their food habit is changing rapidly in the same time to get various health benefits.
Kumar et al. (1987) developed a lassi-type cultured beverage from cheese whey. Kaic and Antomic (1996) mentioned that cultured dairy products have beneficial therapeutic effects such as in reducing lactose intolerance syndrome, preventing gastro-intestinal infections, cardiovascular disease and improving immune defenses. Fermented drinks are good source of probiotic bacteria which plays vital roles in preventing irritable bowel syndrome and colon cancer. There is also an indication that probiotics may play a role in inhibiting Helicobacter pylorie infections which causes ulcers (Santosa et al., 2006).

The demands of fermented dairy products are increasing day by day in Bangladesh. Although fermented dairy products are very much nutritious for maintaining our normal health but due to deficit of raw milk in our country we cannot prepare enough fermented dairy products. So, we have to give emphasize on alternative sources of liquid milk for the production of fermented dairy products. Hence, milk powder might be an alternative source in this respect and 
which can be converted into reconstituted milk for the manufacturing of lassi. Reconstituted milk can easily be prepared by dissolving powdered milk in water. Some research works have been done in the Department of Dairy Science of Bangladesh Agricultural University on lassi preparation by using different concentrations of fat and sugar level from whole milk (Sayed, 2008; Shimu, 2015). No attempts have yet been made to prepare lassi using reconstituted milk. As we have very limited scientific knowledge on different aspects of lassi preparation hence, the present experiment was conducted to monitor the feasibility of using reconstituted milk for preparation of lassi and to get idea about the appropriate level of water to be used for mixing with dahi for the preparation of lassi.

\section{Materials and Methods}

\section{Site and period of experiment}

The experiment was conducted at the Dairy Science Laboratory under the Department of Dairy Science, Bangladesh Agricultural University, Mymensingh during the period of September 29 to December 23, 2015. Whole milk powder was collected from Mymensingh town in Bangladesh.

\section{Reconstituting of milk}

About $875 \mathrm{gm}$ of slightly boiled water was taken in a beaker and $125 \mathrm{gm}$ of whole milk powder (containing $26 \%$ milk fat and $71 \%$ milk SNF) was dissolved slowly in water to produce one $\mathrm{kg}$ of reconstituted milk. Thus, reconstituted milk was prepared in the laboratory.

\section{Chemical analysis of reconstituted milk}

Before manufacturing of lassi, reconstituted milk was prepared and analyzed three times in the laboratory. Specific gravity, total solids, fat, protein, lactose and ash content were determined to know the quality of reconstituted milk samples. Among them, specific gravity was determined using Quevenne's Lactometer and others were determined by using milk analyzer (Lactoscan SLP, MILKOTONIC Ltd., Bulgaria 6000. Stara zagora). The chemical compositions of reconstituted milk are shown in Table 1.

\section{Preparation of lassi}

Reconstituted milk was heated to boiling and there after milk was cold at 40 to $5^{\circ} \mathrm{C}$. At that time, lactic starter culture was added and kept in undisturbed at $37^{\circ} \mathrm{C}$ until coagulation. The coagulated mass (dahi) was used for lassi preparation. Four different types of lassi were prepared by mixing dahi with different levels of water. The prepared lassi were designated as A for lassi prepared by using $15 \%$ water, B for lassi prepared by using $20 \%$ water, C for lassi prepared by using $25 \%$ water and D for lassi prepared by using $30 \%$ water. Sugar level for all lassi samples were similar (20\%). After preparation samples were kept at $5^{\circ} \mathrm{C}$ up to before serving.

Table 1. Chemical composition of reconstituted milk (g/kg)

\begin{tabular}{lc}
\hline Parameters & Amount $\mathbf{( g / K g )}$ \\
\hline Specific gravity & 1.028 \\
Correct lactometer reading & 28.0 \\
Total solids & 122.8 \\
Fat & 42.0 \\
Protein & 33.0 \\
Lactose & 42.6 \\
Solids not fat (SNF) & 81.1 \\
Ash & 7.1 \\
$\mathrm{p}^{\mathrm{H}}$ & 6.7 \\
\hline
\end{tabular}

\section{Physical tests}

Samples were analyzed by a panel of experienced judges for evaluating flavor, color, mouth feel, sweetness and overall physical score.

\section{Chemical tests}

All the samples were chemically analyzed in the laboratory to know the acidity percentage, $\mathrm{pH}$ value, moisture $(\mathrm{g} / \mathrm{kg})$, total solids $(\mathrm{g} / \mathrm{kg})$, fat $(\mathrm{g} / \mathrm{kg})$, protein $(\mathrm{g} / \mathrm{kg})$, carbohydrate $(\mathrm{g} / \mathrm{kg})$ and ash content $(\mathrm{g} / \mathrm{kg})$. The total solids and ash content of the samples were determined by oven drying method according to AOAC (2003). Fat test was performed by Babcock method using the procedure described by Aggarwala and Sharma (1961), protein was determined by Kjeldahal method and $\mathrm{pH}$ value was measured with the help of $\mathrm{pH}$ meter-215 (Ciba Corning Diagnostic Ltd. Sudhury, Suffolk, England Co. 106). Acidity percentage was determined by titrating with $0.1 \mathrm{~N}$ sodium hydroxide solution using the procedure of Aggarwala and Sharma (1961). 


\section{Microbiological tests}

Total viable count (cfu/ml), coliform count $(\mathrm{cfu} / \mathrm{ml})$, yeast and mold count were performed in microbiological assay.

\section{Statistical analysis}

Data obtained from different parameters were analyzed statistically to find out the statistical difference within the treatment means. Analysis of variance test (ANOVA) was carried out by using completely randomized design (CRD). Least significant difference (LSD) values were also determined to rank the samples.

\section{Results and Discussion}

\section{A. Physical parameters}

\section{Flavor}

The flavor score of $A, B, C$ and $D$ type samples were $4.67 \pm 0.58,5.00 \pm 0.00,4.00 \pm 0.00$ and $4.00 \pm 0.00$, respectively (Table 2 ). Result revealed that there was significant difference $(p<0.01)$ among the flavor score of all samples. The highest flavor score was recorded in lassi with $20 \%$ water sample whereas the lowest score was found in lassi with $25 \%$ water and $30 \%$ water samples. Schlicht (1995) and Ahmed (2004) found that addition of fruit improve the flavor of lassi. In this study, no fruits were added but flavor score of lassi with $20 \%$ water was also higher than the other samples which indicate that water level in lassi can influence flavor score.

\section{Color}

The color score of $A, B, C$ and $D$ type samples were $4.00 \pm 0.00,4.67 \pm 0.58,3.00 \pm 0.00$ and $3.00 \pm 0.00$, respectively (Table 2 ). The result showed that significant difference $(p<0.01)$ existed among the color score of all samples.
The highest color score was recorded in case of lassi with $20 \%$ water sample and lowest score was found in lassi with $25 \%$ water and $30 \%$ water samples. This result supported by Begal et al. (2007) and reported that the normal color of lassi varies from yellow to whitish color and which gives good color score.

\section{Sweetness}

Average sweetness score for A, B, C and D type lassi samples were $4.00 \pm 0.00,5.00 \pm 0.00,4.00$ \pm 0.00 and $4.00 \pm 0.00$, respectively (Table 2 ). From the study of sweetness score of all samples, it was found that there was no significant difference $(p>0.05)$ among the all samples. The highest sweetness score was recorded in lassi with $20 \%$ water sample whereas the lowest score was found in lassi with $25 \%$ water and $30 \%$ water samples. Begal et al. (2007) reported that sweetness score of lassi was satisfactory through preparing with $10 \%$ water and $15 \%$ sugar levels but in this study, $20 \%$ sugar and $20 \%$ water combined with reconstituted milk lassi was better than other combinations.

\section{Mouth feel}

Mouth feel score of lassi samples A, B, C, and D were $3.67 \pm 0.58,4.67 \pm 0.58,4.33 \pm 0.58$ and $4.00 \pm 0.00$, respectively (Table 2 ). Statistical analysis showed that there was non-significant difference within mouth feel score of all samples. The highest mouth feel score was recorded in lassi with $20 \%$ water sample and the lowest score was seen in case of lassi with $15 \%$ water sample. Desai et al. (1994) found that mouth feel of yoghurt drink improved due to the addition of fruit juice. In this study, it was found that addition of $20 \%$ water with dahi during lassi preparation improved the mouthfeel score.

Table 2. Comparison of physical parameters scores (mean \pm SD) of lassi containing different levels of water

\begin{tabular}{lcccccc}
\hline Physical Parameters & A & B & C & D & LSD value & Level of significance \\
\hline Flavor (5) & $4.67^{\mathrm{b}} \pm 0.58$ & $5.00^{\mathrm{a}} \pm 0.00$ & $4.00^{\mathrm{c}} \pm 0.00$ & $4.00^{\mathrm{c}} \pm 0.00$ & 0.313 & $*^{* *}$ \\
Color (5) & $4.0^{\mathrm{b}} \pm 0.00$ & $4.67^{\mathrm{a}} \pm 0.58$ & $3.00^{\mathrm{c}} \pm 0.00$ & $3.00^{\circ} \pm 0.00$ & 0.313 & $*^{* *}$ \\
Sweetness (5) & $4.00 \pm 0.00$ & $5.00 \pm 0.00$ & $4.00 \pm 0.00$ & $4.00 \pm 0.00$ & - & $\mathrm{NS}$ \\
Mouthfeel (5) & $3.67 \pm 0.58$ & $4.67 \pm 0.58$ & $4.33 \pm 0.58$ & $4.00 \pm 0.00$ & - & $\mathrm{NS}$ \\
Overall physical score (5) & $4.00 \pm 1.00$ & $5.00 \pm 0.00$ & $4.33 \pm 0.58$ & $4.00 \pm 0.00$ & - & NS \\
\hline
\end{tabular}




\section{Lassi from reconstituted milk}

$a, b, c$ Mean values within a row having different superscripts differ significantly. **Significant at $p<0.01$; NS $=$ non-significant $(\mathrm{p}>0.05)$. Here, A, lassi prepared by using $15 \%$ water; $\mathrm{B}$, lassi prepared by using $20 \%$ water; C, lassi prepared by using $25 \%$ water and D, lassi prepared by using $30 \%$ water.

\section{Overall physical score}

Overall physical score of $A, B, C$ and $D$ type lassi were $4.00 \pm 1.00,5.00 \pm 0.00,4.33 \pm 0.58$ and $4.00 \pm 0.00$, respectively (Table 2 ). Results indicated that non-significant difference $(p>0.05)$ existed among the overall score of all samples. The highest overall score was recorded in lassi with $20 \%$ water sample whereas the lowest score was found in lassi with $30 \%$ water sample. This result indicated that lassi prepared by using dahi from reconstituted milk with a combination of $20 \%$ water and $20 \%$ sugar of the weight of the dahi would produce better quality lassi.

\section{B. Chemical parameters}

\section{Moisture content $(\mathrm{g} / \mathrm{Kg})$}

The average moisture content of samples A, B, C and $D$ type of lassi were $805.03 \pm 0.55,836.17$ $\pm 0.51,838.50 \pm 0.26$ and $845.53 \pm 0.21 \mathrm{~g} / \mathrm{Kg}$, respectively (Table 3 ). Result implied that significant difference $(p<0.01)$ among the moisture content of all samples. The highest moisture value was found in case of lassi with $30 \%$ water sample whereas the lowest value was found in lassi with $15 \%$ water sample. This finding was supported by Sayed (2008) who reported that moisture content of lassi depends on total solids content.

\section{Total solids content $(\mathrm{g} / \mathrm{Kg})$}

The total solids content of samples A, B, C and D type of lassi were $194.97 \pm 0.55,163.83 \pm 0.51$, $161.50 \pm 0.26$ and $154.50 \pm 0.21 \mathrm{~g} / \mathrm{Kg}$, respectively (Table 3 ). From the study of total solids content of all samples, it was found that there was significant difference $(p<0.01)$ among all the samples. The highest TS recorded in lassi with $15 \%$ water sample and the lowest was found in lassi with $30 \%$ water sample (Table 2 ). This result was quite similar with Shimu (2015) who conducted an experiment on lassi preparation and found that total solids of lassi were 109.10 to $149.90 \mathrm{~g} / \mathrm{kg}$.

\section{Fat content $(\mathrm{g} / \mathrm{Kg})$}

The average fat content of $A, B, C$ and $D$ type lassi samples were $35.37 \pm 0.15,34.13 \pm 0.12$, $33.00 \pm 0.00$ and $32.13 \pm 0.00 \mathrm{~g} / \mathrm{Kg}$, respectively (Table 3 ). Result revealed that significant difference $(p<0.01)$ among the fat content of lassi samples. The highest value was recorded in lassi with $15 \%$ water sample followed by lassi with $20 \%$ water and lassi with $25 \%$ water whereas the lowest value was found in lassi with $30 \%$ water sample. This finding was supported by Sayed (2008) who conducted an experiment based on yoghurt drinks with dahi using different fat levels and reported that when water percentage increases then fat content decreases.

\section{Carbohydrate content $(\mathrm{g} / \mathrm{Kg})$}

The carbohydrate content of $A, B, C$ and $D$ type lassi were $129.30 \pm 0.30,100.20 \pm 0.26,100.57$ $\pm 0.38,94.30 \pm 0.20 \mathrm{~g} / \mathrm{Kg}$, respectively (Table 3 ). Statistical analysis showed that there was significant difference $(p<0.01)$ among the carbohydrate content of all lassi samples. The carbohydrate content was higher in lassi with $15 \%$ water sample and the lowest in lassi with $30 \%$ water sample. Higher level of carbohydrate in lassi with $15 \%$ water sample was due to high TS content of that sample. Akhter (2004) reported that carbohydrate content of fermented dairy products influenced by addition of sugar. In this experiment although sugar level was same for all treatments but variations in carbohydrate content was mainly influenced by different water levels of lassi.

\section{Protein content $(\mathbf{g} / \mathbf{K g})$}

Protein content of A, B, C and D type lassi were $24.70 \pm 0.10,23.73 \pm 0.15,22.20 \pm 0.10$ and $22.33 \pm 0.12 \mathrm{~g} / \mathrm{Kg}$, respectively (Table 3 ). There was also significant difference $(p<0.01)$ existed among the protein content of all samples. The highest protein was recorded in lassi with $15 \%$ water sample followed lassi with $20 \%$ water and lassi with $25 \%$ water whereas the lowest value was found in lassi with $30 \%$ water sample. This variation in protein content of lassi samples might be due to addition of different levels of water during lassi preparation. 
Zohra et al. (2016) Bang. J. Anim. Sci. 45 (3): 46-51

Table 3. Chemical composition (mean \pm SD) of lassi containing different levels of water

\begin{tabular}{|c|c|c|c|c|c|c|}
\hline Chemical parameters & A & B & C & D & LSD value & Level of significance \\
\hline Moisture (g/Kg) & $805.03 \pm 0.55$ & $836.17 c \pm 0.51$ & $838.50^{b} \pm 0.26$ & $835.53 a \pm 0.21$ & 0.448 & ** \\
\hline Total solids (g/Kg) & $194.97 a \pm 0.55$ & $163.83^{b} \pm 0.51$ & $161.50^{c} \pm 0.26$ & $154.50^{c} \pm 0.21$ & 0.448 & $* *$ \\
\hline Fat $(\mathrm{g} / \mathrm{Kg})$ & $35.37 a \pm 0.15$ & $34.13^{b} \pm 0.12$ & $33.00^{c} \pm 0.00$ & $32.13^{d} \pm 0.00$ & 0.133 & ** \\
\hline Protein $(\mathrm{g} / \mathrm{Kg})$ & $24.70^{a} \pm 0.10$ & $23.73^{b} \pm 0.15$ & $22.20^{c} \pm 0.10$ & $22.33^{c} \pm 0.12$ & 0.129 & ** \\
\hline Carbohydrate $(\mathrm{g} / \mathrm{Kg})$ & $129.30^{a} \pm 0.30$ & $100.20^{b} \pm 0.26$ & $100.57^{b} \pm 0.38$ & $94.30^{c} \pm 0.20$ & 0.319 & $* *$ \\
\hline Ash $(\mathrm{g} / \mathrm{Kg})$ & $5.77 \pm 0.06$ & $5.37 \pm 0.32$ & $5.70 \pm 0.12$ & $5.60 \pm 0.10$ & - & NS \\
\hline Acidity (\%) & $0.48 \pm 0.01$ & $0.48 \pm 0.01$ & $0.47 \pm 0.01$ & $0.47 \pm 0.01$ & - & NS \\
\hline $\mathrm{pH}$ & $5.63^{b} \pm 0.01$ & $5.70 \mathrm{a} \pm 0.01$ & $5.71 \mathrm{a} \pm 0.01$ & $5.67 \mathrm{ab} \pm 0.01$ & 0.011 & $* *$ \\
\hline
\end{tabular}

$a, b, c$ Mean values within a row having different superscripts differ significantly. $* *$ Significant at $p<0.01 ; N S=$ nonsignificant $(p>0.05)$. Here, A, lassi prepared by using $15 \%$ water; B, lassi prepared by using $20 \%$ water; C, lassi prepared by using $25 \%$ water and $\mathrm{D}$, lassi prepared by using $30 \%$ water.

\section{Ash content $(\mathrm{g} / \mathrm{Kg})$}

The ash content of $A, B, C$ and $D$ type samples were $5.77 \pm 0.06,5.73 \pm 0.32,5.70 \pm 0.12$ and $5.60 \pm 0.10 \mathrm{~g} / \mathrm{Kg}$, respectively (Table 3 ). Ash content of all the samples differed nonsignificantly $(p>0.05)$ and average ash content of lassi with $15 \%$ water sample was slightly higher than other samples. Ash content of lassi of this experiment was nearly similar to the findings of Sayed (2008) who reported that ash content varied from $6.4-7.0 \mathrm{~g} / \mathrm{kg}$.

\section{Acidity percentage}

Average acidity percentage for $A, B, C$ and $D$ type lassi samples were $0.48 \pm 0.01,0.48 \pm 0.01$, $0.47 \pm 0.01$ and $0.47 \pm 0.01 \%$, respectively (Table 3). Research result showed that acidity percentage was slightly lower in lassi with $30 \%$ water sample than other samples but there was non-significant difference $(p>0.05)$ existed among the samples (Table 3 ). This slight variation in acidity level of different samples was due to dilution effect of water in lassi. Also, Shimu (2015) found the acidity of lassi was 0.45$0.47 \%$ which was quite similar with the present research findings.

\section{pH value}

The $\mathrm{pH}$ value of $\mathrm{A}, \mathrm{B}, \mathrm{C}$ and $\mathrm{D}$ type lassi were $5.63 \pm 0.01,5.70 \pm 0.01,5.71 \pm 0.01$ and 5.67 \pm 0.01 , respectively (Table 3 ). Statistical analysis revealed that there was significant difference $(p<0.01)$ among the $\mathrm{pH}$ content of all lassi samples. It also evidenced that $\mathrm{pH}$ content was higher in lassi with $25 \%$ water sample whereas lower in lassi with $15 \%$ water sample. The result of this present investigation agreed with the findings of Sayed (2008) and Shimu (2015).

\section{Microbiological parameters}

\section{Total viable count (cfu/mL)}

The total viable count of A, B, C and D type lassi are shown in Table 4. Research findings showed that there was significant difference $(p<0.01)$ among the different lassi samples. The highest total viable count was found in lassi prepared by using $15 \%$ water sample and which was $94.67 \times 10^{4} \pm 0.58$. Ahmed (2004) found $87.00 \times 10^{4}$ to $89.66 \times 10^{4} \mathrm{cfu} / \mathrm{mL}$ total viable bacteria in yoghurt drink samples and which was quite similar with these findings.

\section{Coliform count (cfu/mL)}

The coliform bacterial count of A, B, C and D type lassi are shown in Table 4 and which indicated that coliform bacterial count was very low in all types of lassi samples. Result showed that there was no significant difference ( $p>0.05)$ among the different lassi samples. Lower coliform count indicates that the quality of lassi was maintained hygienically and sanitation condition was good. This finding was similar with Ahmed (2004) who found that there were no coliform bacteria in yoghurt drink samples. 
Table 4. Microbiological qualities (mean \pm SD) of lassi containing different levels of water

\begin{tabular}{lcccccc}
\hline Parameters & A & B & C & D & LSD value & Level of significance \\
\hline Total viable count $\left(\times 10^{4}\right)$ & $94.67 \mathrm{a} \pm 0.58$ & $90.33^{\mathrm{b}} \pm 1.53$ & $86.00^{c} \pm 5.57$ & $82.33^{\mathrm{d}} \pm 2.08$ & 3.351 & \\
Coliform count $(\times 10)$ & $1.33 \pm 0.58$ & $1.33 \pm 0.58$ & $0.33 \pm 0.58$ & $0.33 \pm 0.58$ & - & NS \\
Yeast count $(\times 10)$ & $1.67 \pm 0.58$ & $1.33 \pm 1.15$ & $1.00 \pm 0.00$ & $1.00 \pm 0.0$ & - & NS \\
Mold count $(\times 10)$ & $1.00 \pm 0.0$ & $0.33 \pm 0.58$ & $0.33 \pm 0.58$ & $0.33 \pm 0.58$ & - & NS \\
\hline
\end{tabular}

$a, b, c$ Mean values within a row having different superscripts differ significantly. $* *$ Significant at $p<0.01 ; N S=$ nonsignificant ( $p>0.05$ ). Here, A, lassi prepared by using $15 \%$ water; B, lassi prepared by using $20 \%$ water; C, lassi prepared by using $25 \%$ water and $\mathrm{D}$, lassi prepared by using $30 \%$ water.

\section{Yeast count}

Average yeast count of $A, B, C$ and $D$ type lassi are shown in Table 4 and statistical analysis showed that there was no significant difference ( $p>0.05)$ among the different lassi samples. The yeast count was very few due to maintaining of good sanitary condition as well as using of good bacterial starter culture and the result agreed with the findings of Ahmed (2004).

\section{Mold count}

The mold count of $A, B, C$ and $D$ type lassi are shown in Table 4 and statistically there was no significant difference $(p>0.05)$ among the mold content of different lassi samples. The mold count was also very few like viable and coliform count due to maintaining of good sanitary condition and this result was nearly similar with the result of Ahmed (2004).

\section{Conclusion}

From the findings of this study, it might be concluded that lassi could be prepared successfully from reconstituted milk. Although some parameters values were slightly higher in lassi with $15 \%$ water but judges prefer lassi with $20 \%$ water. Therefore, in respect of physical, chemical and microbiological qualities $20 \%$ water along with $20 \%$ sugar was better than others for manufacturing of lassi from reconstituted milk when there is shortage of whole liquid milk.

\section{References}

Aggarwala AC and RM Sharma (1961). A Laboratory Manual of Milk Inspection. $4^{\text {th }}$ edition. Asia Publishing House. Bombay, Kolkata, New Delhi, India.

Ahmed S (2004). Studies on the manufacture of flavored yoghurt drinks from skim milk. MS Thesis, Department of Dairy Science, Bangladesh Agricultural University, Mymensingh.

Akter N (2004). The effect of different levels of starter culture and sugar on fermentation characteristics of Misti Dahi. MS Thesis, Department of Dairy Science, Bangladesh Agricultural University, Mymensingh, Bangladesh.

AOAC (2003). Official Methods of Analysis. $15^{\text {th }}$ edition. Association of Official Analytical Chemists, Arlington, Virginia, USA.

Begal SG, KD Chavan and MB Kalkarni (2007). Studies on preparation of lassi from high acid cow milk. Journal of Dairying, Foods and Home Sciences, 26(2): 80-84.

Desai SR, VA Toro and SV Joshi (1994). Utilization of different fruits in the manufacture of yoghurt. Indian Journal of Dairy Science, 47(10): 870874.
Kaic RA and D Antonic (1996). Nutritional and Biological value of cultured milk products. Mijekarstovo, 46(4): 285-290.

Kumar R, GR Patil and RB Rajor (1987). Development of lassi-type cultured beverage from cheese whey. Asian journal of Dairy Research, 6(3): 121-124.

Santosa S, E Farnworth and PJH Jones (2006). Probiotics and their potential health claims. Nutrition Reviews, 64: 265-274.

Sayed MS (2008). Preparation of yoghurt drinks with different fat level of dahi. MS Thesis, Department of Dairy Science, Bangladesh Agricultural University, Mymensingh.

Schlicht R (1995). New yoghurt drink in a new packaging concept. ZFL Internationale Zeitschrift Fur Lebensmittel Technik, Marketing. Verpackung and Analystik, 46(10): 60-62.

Shimu SN (2015). Comparative study of yoghurt drinks prepared from skim milk and whole milk. MS Thesis, Department of Dairy Science, Bangladesh Agricultural University, Mymensingh. 